\title{
Littoral cell angioma of spleen: A seldom-vascular tumour and a rare cause of long-standing anaemia with thrombocytopenia
}

\author{
Kruti Dave $^{1 *}$, Shwetang Solanki ${ }^{2}$ and Imran Zindani ${ }^{1}$ \\ ${ }^{1}$ Jivraj Mehta Hospital, Gujarat, India \\ ${ }^{2}$ Shalby Hospital, Gujarat, India
}

\begin{abstract}
Littoral cell angioma is a seldom recently described primary vascular neoplasm of the spleen. It is usually benign but may itself also have malignant potential. The tumor arises from the littoral cells in the splenic red pulp sinuses. However, the radiologic features of littoral cell angioma are rarely diagnostic, histopathology association would be helpful.
\end{abstract}

\section{Introduction}

Littoral cell angioma is a seldom recently described primary vascular neoplasm of the spleen. It is usually benign, but may also have malignant potential. The tumour arises from the littoral cells in the splenic red pulp sinuses. Usually, patients with littoral cell angioma have anaemia or thrombocytopaenia. Most of the cases of littoral cell angioma have been reported as multiple nodules of varying sizes in the spleen; only a few have been described with of focal angioma.

\section{Case presentation}

A 49-year-old woman presented with abdominal pain, weakness, breathlessness and fatigue in our hospital. She had intermittent episodes of left upper quadrant pain. There was no history of nausea or vomiting. She had a 6-year history of iron deficiency anemia and recent history of thrombocytopenia. All vitals were stable on admission. On physical examination, she was found to have splenomegaly. Blood examination showed moderate anemia; liver and renal function tests were normal.

On ultrasonography examination, there was gross splenomegaly with diffusely scattered multiple hypo echoic nodular lesions and multiple small cysts in spleen were noted. Contrast enhanced abdominal computed tomography scan revealed gross splenomegaly (measuring about 19.3 centimeters in size) with multiple, diffusely, scattered, varying size non enhancing hypo dense nodular lesions and multiple small cysts in spleen (Figure 1). Splenic vein was mildly dilated and measures about $13 \mathrm{~mm}$ in diameter (Figure 2). Our provisional diagnosis was lymphoma or haemangioma. After patient underwent splenectomy, the gross cut surface of the spleen showed multiple nodules with blood (Figure 3A) and immunohistochemical report showed a hybrid endothelial-histiocytic phenotype confirmed the diagnosis of littoral-cell angioma (Figure 3B).

\section{Discussion}

Littoral cell angioma of the spleen is a seldom-vascular tumor that was first described by Falk et al The tumour arises from the littoral cells in the splenic red pulp sinuses [1].

The incidence of littoral cell angioma is yet to be determinate but the incidence of splenic haemangioma varies from $0.03 \%$ to $14 \%$ by Wilcox et al [2]. There is no specific age or sex predilection with littoral cell angioma.

The pathogenesis of littoral cell angioma is not very clear; however there can be associations with other diseases like Crohn's disease or Gaucher's disease and malignancies like pancreatic or colorectal carcinomas [3].

It is usually benign but it may have malignant potential $[4,5]$. However, there are two subtypes with malignant potential that have been described as "littoral cell angiosarcoma" [6,7] and "littoral cell haemangioendothelioma" [8].
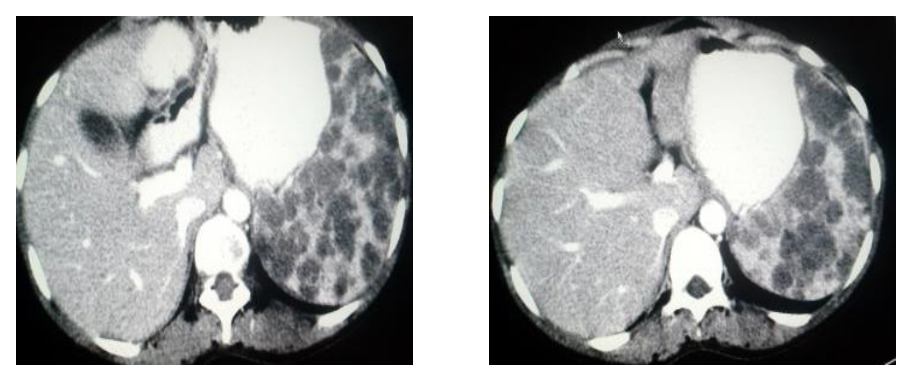

Figure 1. CT scan after oral and iv-contrast demonstrates multiple, diffusely, scattered, varying sized non enhancing hypodense nodular lesions and multiple small cysts in spleen.

Correspondence to: Kruti Dave, Jivraj Mehta Hospital, Gujarat, India, E-mail: dave.kruti@gmail.com

Key words: littoral cell angioma, spleen, immunohistochemistry

Received: March 03, 2016; Accepted: April 18, 2016; Published: April 21, 2016 


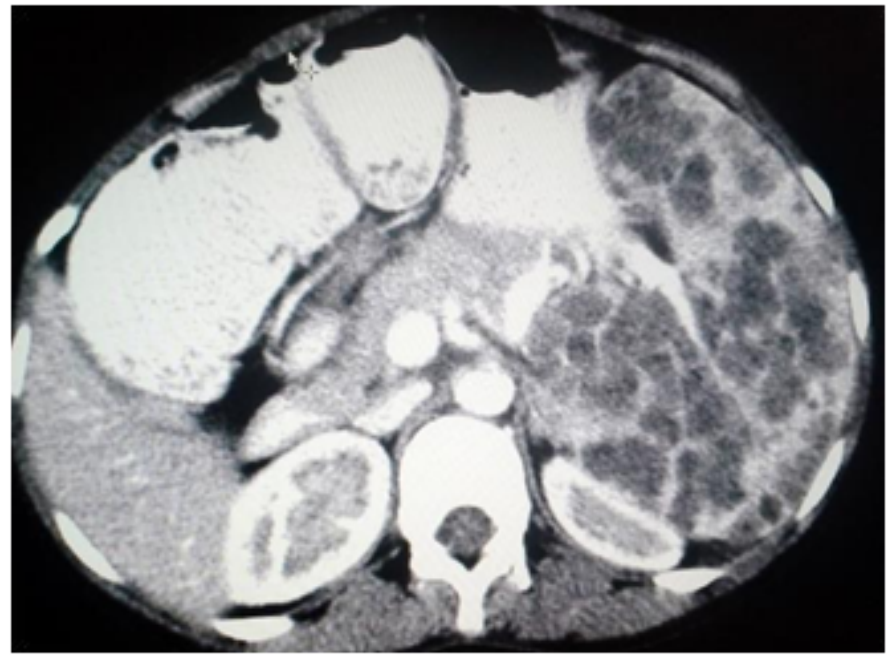

Figure 2. Computed tomography image of the abdomen showing mildly dilated splenic vein with multiple scattered splenic nodules.

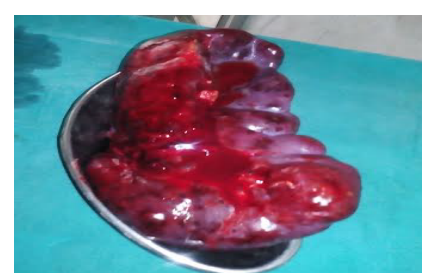

(A)

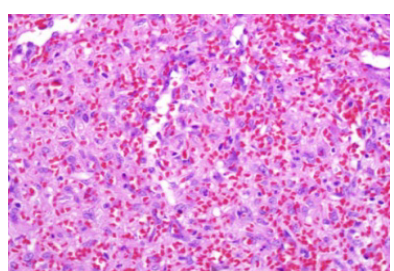

(B)
Figure 3. (A) Gross cut surface of the spleen showed nodules with blood and (B) histopathology slide showed a hybrid endothelial-histiocytic phenotype.

The definite diagnosis of littoral cell angioma can only be made at pathology after splenectomy. The gross cut surface of the spleen shows multiple nodules with blood or blood products with a variable color from dark red or brown to black, depending on the chronicity of the blood in the lesion.

Radiologically, it is difficult to give littoral cell angioma as the primary diagnosis as it is quite uncommon and its imaging features overlap with other commoner diseases. Ultrasonography, computed tomography scans and magnetic resonance imaging are modalities that can be used in its diagnosis. On ultrasonography, the findings can be splenomegaly with multiple nodules, which are either hypoechoic or hyperechoic. On computed tomography scan, these nodules appear hypodense with low enhancement in few of the nodules [9]. Radiologically, differential diagnosis of littoral cell angioma includes lymphoma, metastases, infectious disease and haemangioma [10]. Nuclear medicine studies with Tc-99m labelled RBC scintigraphy can be useful to differentiate splenic lesions from splenic haemangiomas.

Medical treatment with glucocorticoids and angioembolization of splenic haemangiomas may be useful [11]. However, splenectomy is considered the gold standard for treatment.

\section{Conclusion}

Littoral cell angioma is a rare usually benign, primary vascular tumor of the spleen. However, the radiologic features of littoral cell angioma are rarely diagnostic, histopathology association would be helpful. Splenectomy is considered the gold standard for treatment.

\section{References}

1. Falk S, Stutte HJ, Frizzera G (1991) Littoral cell angioma. A novel splenic vascular lesion demonstrating histiocytic differentiation. Am J Surg Pathol 15: 1023-1033. [Crossref]

2. Willcox TM, Speer RW, Schlinkert RT, Sarr MG (2000) Hemangioma of the spleen presentation, diagnosis, and management. J Gastrointest Surg 4: 611-613.[Crossref]

3. Gupta MK, Levin M, Aguilera NS, Pastores GM (2001) Littoral cell angioma of the spleen in a patient with Gaucher disease. Am J Hematol 68: 61-62.[Crossref]

4. Fernandez S, Cook GW, Arber DA (2006) Metastasizing splenic littoral cell hemangioendothelioma. Am J Surg Pathol 30: 1036-1040.[Crossref]

5. Ben-Izhak O, Bejar J, Ben-Eliezer S, Vlodavsky E (2001) Splenic littoral cell haemangioendothelioma: a new low-grade variant of malignant littoral cell tumour. Histopathology 39: 469-475.[Crossref]

6. Rosso R, Paulli M, Gianelli U, Boveri E, Stella G, et al. (1995) Littoral cell angiosarcoma of the spleen. Case report with immunohistochemical and ultrastructural analysis. Am J Surg Pathol 19: 1203-1208.[Crossref]

7. Rosso R, Paulli M (2004) Littoral cell angiosarcoma: a truly malignant tumor. Am J Surg Pathol 28: 1255.[Crossref]

8. Ben-Izhak O, Bejar J, Ben-Eliezer S, Vlodavsky E (2001) Splenic littoral cel haemangioendothelioma: a new low-grade variant of malignant littoral cell tumour. Histopathology 39: 469-475.[Crossref]

9. Giovagnoni A, Giorgi C, Goteri G (2005) Tumours of the spleen. Cancer Imaging 5 73-77.[Crossref]

10. Bhatt S, Huang J, Dogra V (2007) Littoral cell angioma of the spleen. AJR Am J Roentgenol 188: 1365-1366.[Crossref]

11. Islam S, Newman EA, Strouse PJ, Geiger JD (2005) Antiangiogenic therapy for a large splenic hemangioma. Pediatr Surg Int 21: 1007-1010.[Crossref]

Copyright: (C2016 Dave K. This is an open-access article distributed under the terms of the Creative Commons Attribution License, which permits unrestricted use, distribution, and reproduction in any medium, provided the original author and source are credited. 